\author{
Yaroslav Kornienko, Vasyl Raida, Roman Sachok and Oleksiy Tsepkalo
}

\title{
MATHEMATICAL MODELLING OF CONTINUOUS FORMATION OF MULTILAYER HUMIC-MINERAL SOLID COMPOSITES
}

\author{
National Technical University of Ukraine "Kyiv Polytechnic Institute" \\ 37, Prospekt Peremohy, 03056 Kyiv \\ che@users.ntu-kpi.kiev.ua
}

Received: M arch 23, 2009

@ Kornienko Y., Raida V., Sachok R., Tsepkalo O., 2009

\begin{abstract}
A mathematical model of continuous granulation process of solid multilayer humic-mineral composites in the fluidized bed unit intended for liquid industrial wastes utilization with obtaining of complex granular fertilizers for environmentally safe agriculture was developed and the stabilization terms of the dispersion composition were defined.
\end{abstract}

Keywords: mathematical model, humic-mineral composites, granulation process, liquid wastes.

\section{Introduction}

Aggravation of ecological problems in the conditions of post-industrial society requires introduction of new principles of the use of natural resources. In this context one of the top priority tasks for Ukraine is suspension of fertile soils exhaustion, which amount to more than $70 \%$ of its national wealth.

Therefore development of the technology of obtaining new generation of organomineral granulated fertilizers with a variable ratio of nourishing and stimulative substances, which are defined by agro-ecological and soil-climatic conditions of the their employment region, is very actual.

The authors $[1,2]$ determined that the humic substances content should not exceed $1-2 \%$ in relation to dry substances, whereas the mineral N:P:K components amount to $10-20 \%$.

Long-term agricultural observations discovered high efficiency of humic-mineral fertilizers, particularly on acid soils in the presence of calcium admixtures in their composition in the amount of 5-8\% [2].

Consequently, the basic requirement is equal distribution of the components in the overall volume of the spherical granule with the size of 1.5-4.5 mm, which have durability not less than $7 \mathrm{~N}$ per granule.

The authors [3] suggested a way of obtaining solid multilayer humic-mineral solid composites in a fluidized bed unit.

\section{Mathematical Model}

According to the authors [5] the mathematical model is based on the continuity equation, which after development by the authors [5] was written in partial derivatives as follows:

$$
\begin{aligned}
& \frac{\partial g}{\partial \tau}+2\left[\Lambda \frac{\partial g}{\partial D}+g \frac{\partial \Lambda}{\partial D}-\frac{3 \Lambda g}{D}\right]= \\
& =-S \psi K g+\varphi(D), \tau>0,0<\mathrm{D}<\infty
\end{aligned}
$$

where $g$ is the function of the particles distribution according to the diameter, $\mathrm{mm}^{-1} ; t$ is the time, $\mathrm{h} ; D$ is the current grain diameter, $\mathrm{mm} ; \Lambda$-is the linear growth velocity, $\mathrm{mm} / \mathrm{h} ; S$ is the separator function; $\psi$ is the grain formation coefficient, stakes; $K$ is the unload constant, $\mathrm{h}^{-1} ; \varphi$ is the source and flow function of the granules, $(\mathrm{mm} \cdot \mathrm{h})^{-1}$

$$
\text { If we take zero order of the grain growth } \frac{\partial \Lambda}{\partial D}=0 \text {, }
$$

then the equation (1) takes on the following form:

$$
\begin{gathered}
\frac{\partial g}{\partial \tau}+2\left[\Lambda \frac{\partial g}{\partial D}-\frac{3 \Lambda g}{D}\right]= \\
=-S \psi K g+\varphi(D), \tau>0,0<\mathrm{D}<\infty
\end{gathered}
$$

Hence the source and flow function is defined as

$$
\varphi(D)=\frac{\partial g}{\partial \tau}+2\left[\Lambda \frac{\partial g}{\partial D}-\frac{3 \Lambda g}{D}\right]+S \psi K g
$$

For a stable process, when $\frac{\partial g}{\partial \tau}=0$ equation acquires the following form: 


$$
\varphi(D)=2\left[\Lambda \frac{\partial g}{\partial D}-\frac{3 \Lambda g}{D}\right]+S \psi K g
$$

To solve this equation parameters $\mathrm{G}, \psi, \mathrm{K}$, and $\Lambda$ need to be defined experimentally.

The experimental research of the formation process of multilayer humic-mineral solid composites was carried out on the pilot unit with geometrical sizes of the grainer chamber of $\mathrm{A} \times \mathrm{B} \times \mathrm{H}=0.1 \times 0.3 \times 1.2 \mathrm{~m}$.

\section{Results and Discussion}

Dynamics of the granules equivalent diameter shift in the fluidized bed while obtaining humic-nitric fertilizers of $\mathrm{H}: \mathrm{N}=1: 20$, humic-nitrogenous-calcic $(\mathrm{H}: \mathrm{N}: \mathrm{Ca}=$ 1:15:12), and humic-nitrogenous-potassic-calcic ( $\mathrm{H}: \mathrm{N}: \mathrm{K}: \mathrm{Ca}$ $=1: 15: 8: 12)$ compositions is given in Fig. 1 .

Granules intensive equivalent diameter enlargement in the unit indicates steady kinetics of the grain formation with high efficiency of $\psi=90-95 \%$, but with undercapacity of the internal source of new granulation centres creation.

Some generalizations of the experimental results showed that $\gamma$-distribution with the accuracy of 0.95 describes the fluidized bed dispersed composition:

$$
g=\frac{Z^{n}}{(n-1) !} D^{*(n-1)} \cdot e^{-z D^{*}}
$$

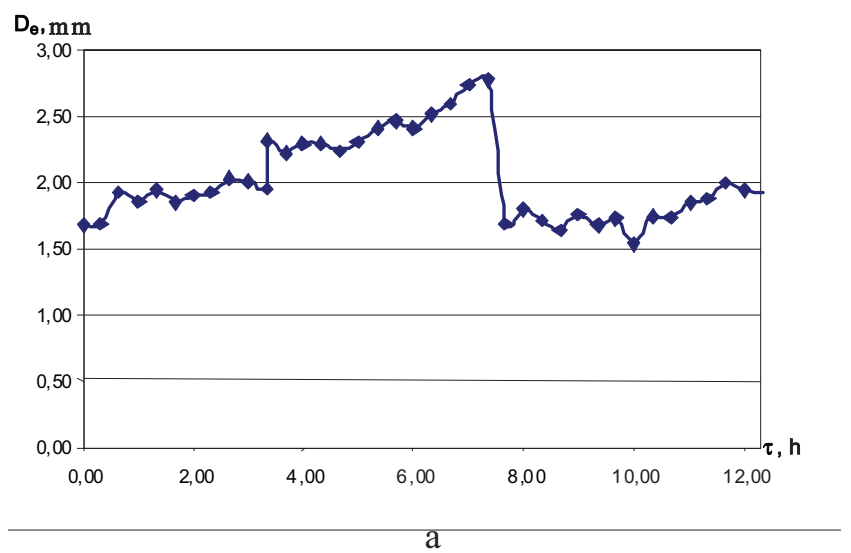

Fig. 1. Dynamics of the granules equivalent diameter shift in the fluidized bed while obtaining of humic- nitrogenous (a), humic- nitrogenous-calcic (b) and humic- nitrogenouspotassic-calcic (c) composites where $n$ and $z$ are parameters of $\gamma$-distribution, which values have been experimentally defined and presented in the table and $\mathrm{D}^{*}-$ is a reduced diameter.

\begin{tabular}{|c|l|c|c|c|}
\hline & $\begin{array}{l}\text { Chemical composition of } \\
\text { fertilizers }\end{array}$ & $\mathrm{n}$ & $\mathrm{Z}$ & $\mathrm{n} / \mathrm{Z}$ \\
\hline 1 & humic- nitrogenous & 25 & 11 & 2.27 \\
\hline 2 & humic-nitrogenous-calcic & 14 & 6 & 2.30 \\
\hline 3 & $\begin{array}{l}\text { humic- nitrogenous- } \\
\text { potassic-calcic }\end{array}$ & 12 & 5.2 & 2.31 \\
\hline
\end{tabular}

To meet the requirements to dispersed composition of the finished product mass distribution of the granules in the fluidized bed, Fig. 2 curve 1 and approximation by $\gamma$-distribution for the three types of humic-mineral fertilizers are presented in Fig. 2, curve 2.

The source and flow function of the particles calculated in equations (3) and (4) using the experimental results while obtaining humic-mineral fertilizers of various chemical composition at general flow of the granulated product, $\mathrm{S}=1$, is given in Fig. 3 .

The peculiarity of the presented dependencies $\varphi(D)=f\left(D_{i}\right)$ is a sinusoid, whose positive wing characterizes the power of the source of new granulation centres while the negative one depicts unloading and grinding of large granules (stock) in the range of $2.5<D_{i}<5.0 \mathrm{~mm}$ (Fig. 3), for stable mode when $\frac{\partial g}{\partial \tau}=0$, (Fig. 3,
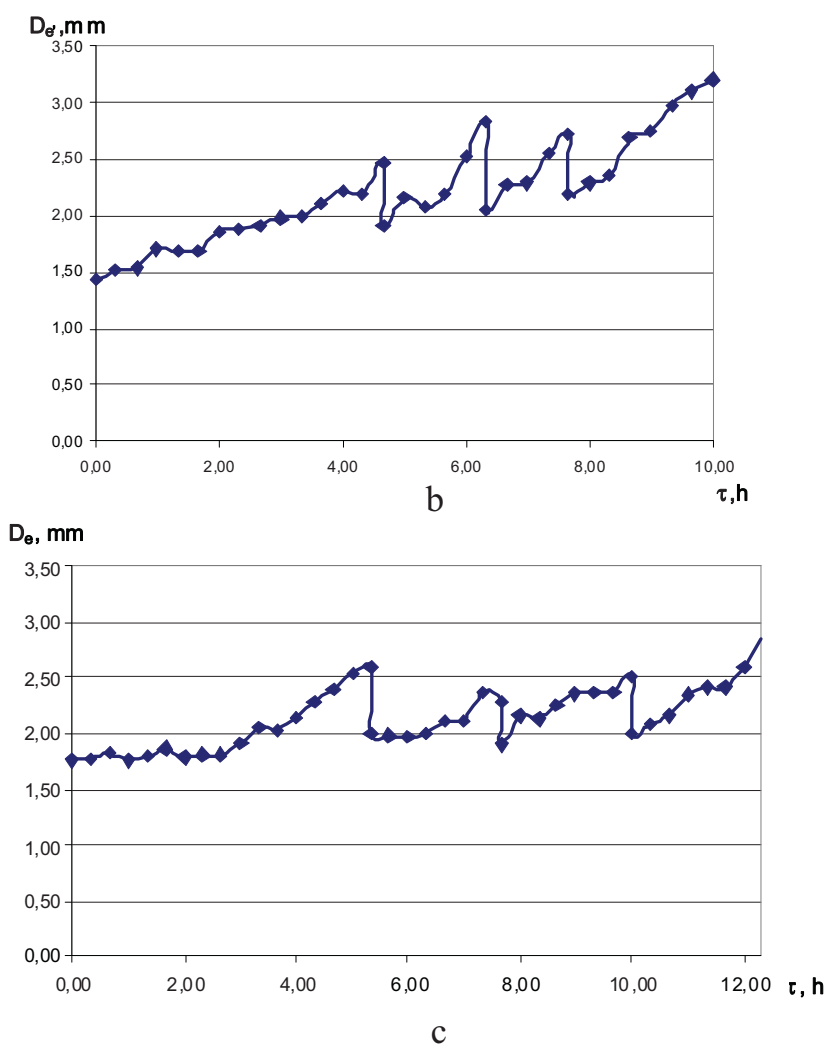


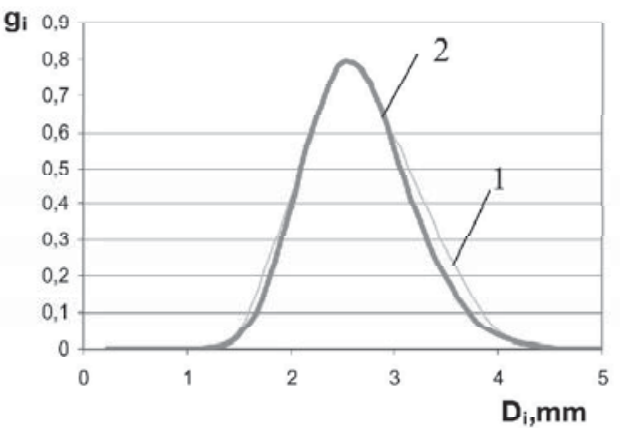

a

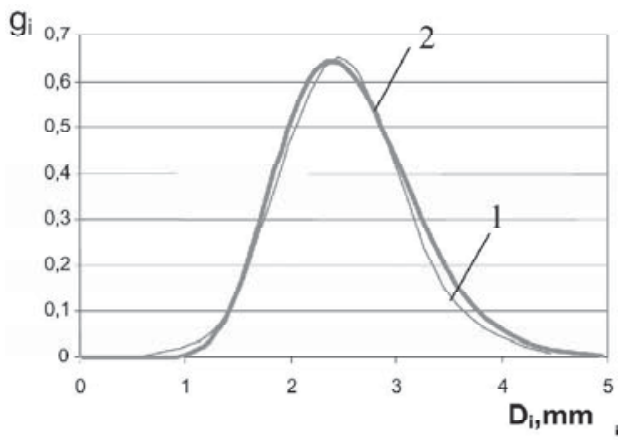

c

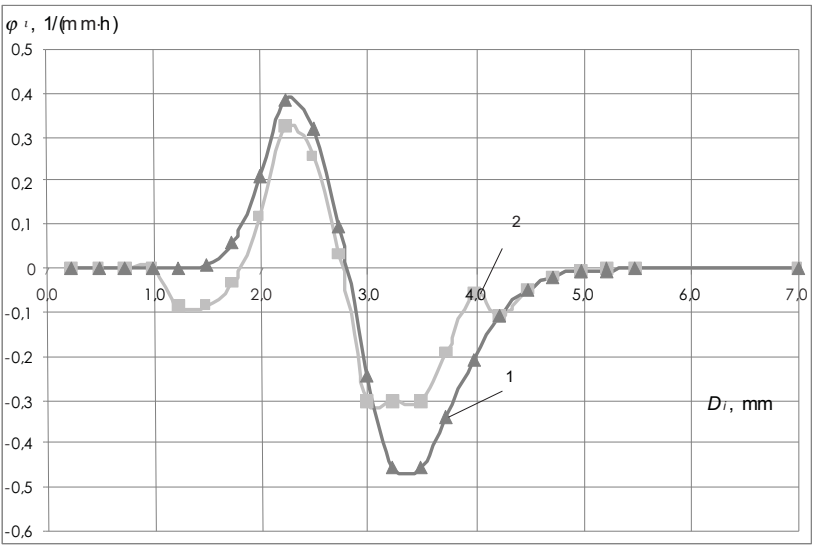

a

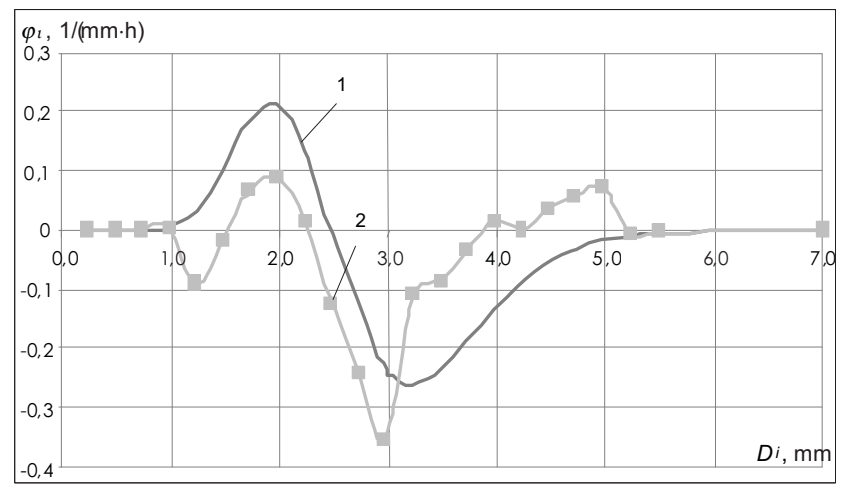

$\mathrm{c}$

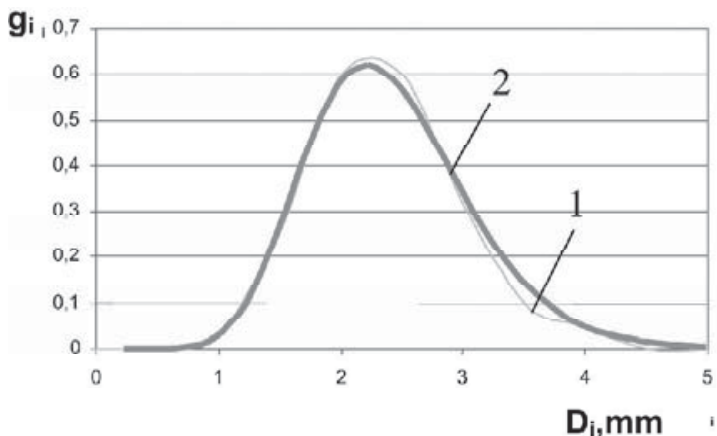

b

Fig. 2. Approximation of the grain mass distribution in the unit for humic- nitrogenous (a), humic-nitrogenous-calcic (b) and humic- nitrogenous-potassic-calcic (c) composites. 1 - experimental distribution; 2 - calculated distribution

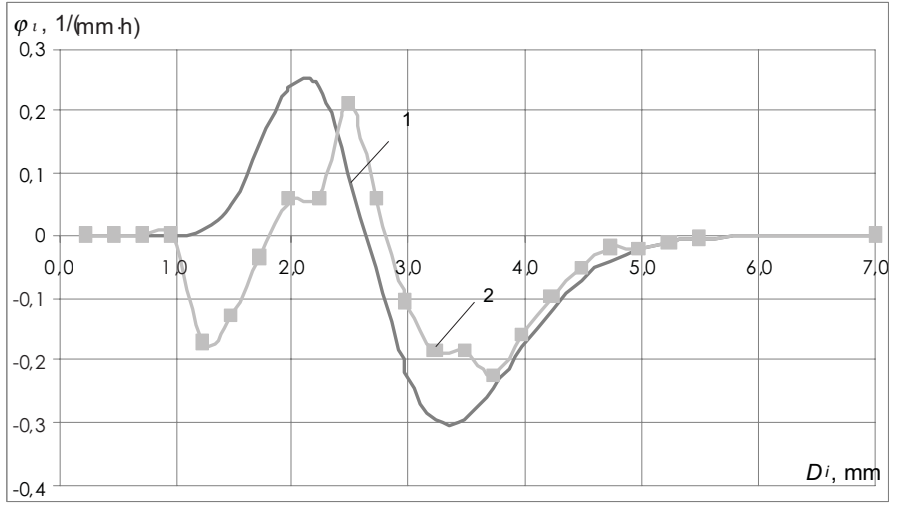

$\mathrm{b}$

Fig. 3. Source and flow function of the grain new centres while obtaining humic- nitrogenous (a), humic-nitrogenous-calcic (b) and humic-nitrogenouspotassic-calcic (c) composites. 1 - stable process; 2 - unstable process 



c

curves 1) and for nonsteady process $\frac{\partial g}{\partial \tau} \neq 0$ (Fig. 3, curves 2).

In the case of a nonsteady process, when $\frac{\partial g}{\partial \tau} \neq 0$, curves 2 plotted on the basis of the research data, (see Fig. 3), have significant deviations from the stable process, and at $D_{i}<1.8 \mathrm{~mm}$ function $\varphi(D)$ acquires negative values. This gives evidence of an insufficient power of the internal source of the new granulation centres and as a result the particles number misbalance in the unit.

Application of selective unloading significantly increases power of the internal sources of granulation centres (see Fig. 4, curves 1 and 2). This makes it possible to substantially influence the dynamics of change of dispersion composition of fluidized bed layer in the unit.

The presence of deviation in the positive part of the function spectrum $\varphi\left(D_{i}\right)$ testifies to insufficient power of the internal source of new centres, which needs to be compensated by external factors.

\section{Conclusions}

The suggested mathematical model adequately describes the continuous granulation process of multilayer humic-mineral solid composites under the conditions of steady kinetics with the values of granulation coefficient of $\psi \geq 94 \%$. It has been defined that $\gamma$-distribution with

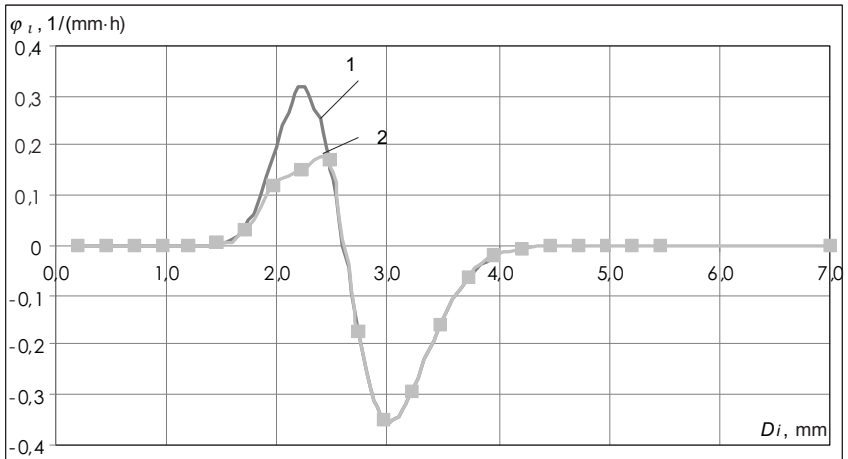

b

Fig. 4. Function of the power of source and stock of new granulation centres for humic-nitrogenous (a),

humic-nitrogenous-calcic (b) and c)humic-nitrogenouspotassic-calcic (c) composites. 1 - disregarding separation; 2 - taking into account separation

the accuracy of 0.95 describes the dispersion composition of granules in the unit for complex humic-mineral fertilizers. For different humic-mineral multilayer composites functions of dispersion composition stabilization conditions have been defined.

\section{References}

[1] Gorovaya A., Orlov D. and Tsherbenko O.: Guminovye veshchestva. Stroenie, funkcii, mehanismy deistvia, protektornye svoistva, ekologicheskaya rol. Naukova dumka, Kiev 1995.

[2] Kornienko Y., Zagray Y. and Budjerac A.: Naukovi Visti NTUU “KPI”, 2001, 3, 129.

[3] Zagray Y. and Kornienko Y.: Pat. 4465 Ukraine, MKP C05 G 1/00. Publ. Dec. 27,.1994.

[4] Todes O., Kaganovych Yu., Seballo V. et al.: Obezvogivanie rastvorov v kipyashem sloe. Metalurgia, Moskwa 1973.

[5] Kornienko Ya.: Naukovi visti NTUU “KPI", 2000, 2, 38.

\section{МАТЕМАТИЧНЕ МОДЕЛЮВАННЯ БЕЗПЕРЕРВНОГО УТВОРЕННЯ БАГАТОШАРОВИХ ГУМІНОВО- МІНЕРАЛЬНИХ ТВЕРДИХКОМПОЗИТІВ}

Анотація. Розроблено математичну модель безперервного процесу гранулоутворення твердих багатошарових гуміново-мінеральних композитів в апараті псевдозрідженого шару утилізачії рідких промислових відходів з отриманням комплексних гранульованих добрив для екологічно безпечного землеробства і визначені умови стабілізачії дисперсного складу.

Ключові слова: математична модель, гуміновомінеральні композити, гранулоутворення, рідкі відходи. 